\section{Geological Society of Turkey}

THE Geological Society of Turkey (Türkiye Geoloji Kuruma) was officially founded in June 1946 at Ankara. The headquarters are in the Institute of Mining Research, Ankara, and the officers are : President, Prof. H. N. Pamir; Vice-President, Dr. M. R. Egemen; Secretary, Dr. G. Otkun; Treasurer, M. Tasman. The objects of the Society are to promote geological research and encourage the study of geology, and to foster contact and collaboration between the various branches of applied geology. Its activities include conferences, lectures and discussions on geological topics; geological excursions both in Turkey and abroad; publication of a bulletin and memoirs of original research; establishment of a library; maintenance of close relations with similar bodies abroad and participation at international geological congresses. Much has already been done since the founding of the Society. Two conferences and an excursion have been held in Ankara, the first of which (February 24-28) comprised papers on local geology, including a comparison of Scotland and Turkey by Prof. W. J. McCallien, of the University of Ankara, and on petrology and geophysics, and a whole-day excursion to the Haymana region south of Ankara. Preparations are now being made for the publication of the first bulletin. The present membership is one hundred, and there are twelve foreign members and correspondents.

\section{South-Eastern Union of Scientific Societies}

THE fifty-first annual congress of the SouthEastern Union of Scientific Societies will be held at Brighton during July 14-19. The Corporation of Brighton has put the Royal Pavilion at the disposal of the Congress. The president-elect is Prof. W. A. F. Balfour-Browne, who will give an address on "The Possibilities of Natural History". The sectional presidents are E. J. Bedford (botany), A. H. Toms (geology), J. E. Ray (archæology), Prof. G. D. Hale Carpenter (zoology). A morning session will be devoted to a discussion on "The Place of Scientific Societies in the Promotion of Science", based on a circular letter received from the British Association. There will be an evening public lecture and film, "The Beginning of History", dealing with British prehistory, the introductory lecture being given by E. Cecil Curwen, and a film programme for schools designed to promote interest in local natural history and archæology. The honorary general secretary of the Union is H. M. Montford, 23 Mountside, Guildford, Surrey, from whom particulars of the Congress can be obtained.

\section{University of London}

THE following appointments have been announced : Dr. K. J. Franklin, acting director of the Nuffield Institute for Medical Research, Oxford, to the University chair of physiology tenable at St. Bartholomew's Hospital Medical College, as from October 1; Dr. Margaret M. A. Murray, since 1925 lecturer in physiology at Bedford College, to the University chair of physiology tenable at the College, as from October 1 ; Dr. Margaret Fishenden, during 1932-45 honorary lecturer in the Mechanical Engineering Department at the Imperial College of Science and Technology and since 1945 senior lecturer in heat transmission, to the University readership in applied heat tenable at the College, as from October $1 ; \mathrm{Mr}$. H. E. O. James, since 1926 lecturer in psychology at the
University of Manchester, to the University readership in psychology tenable at the Institute of Education, as from October 1 .

The title of reader in commerce in the University has been conferred on Mr. Frederick Brown, in respect of the post held by him at the London School of Economics; the title of reader in electrical engineering in the University has been conferred on Mr. C. R. Stoner, in respect of the post held by him at Queen Mary College.

The degree of doctor of science has been conferred on W. J. Martin (Birkbeck College and the London School of Hygiene and Tropical Medicine) and on K. R. S. Morris (external student).

\section{"The Corpus Allatum and the Control of Meta- morphosis in Insects"}

DR. V. B. WIGGLESWORTH writes: "In my letter in Nature of June 28 , p. 872 , I omitted, by an oversight, any reference to the important observation by Vogt that the corpus allatum of the first-stage larva of Drosophila hydei will induce egg production when implanted into the allatectomized adult female (Biol. $Z b l ., 63,467$; 1943). This provides further evidence for the identity of the juvenile and yolk-forming hormones."

\section{Announcements}

Prof. Linus Pauling, professor of chemistry in the California Institute of Technology, has been appointed George Eastman visiting professor in the University of Oxford for the Hilary and Trinity terms, 1948.

Mr. J. L. Adam, chief surveyor to the British Corporation of Shipping and Aircraft, has been elected president, and Dr. J. H. Paterson vicepresident, of the Institute of Welding.

DR. H. L. Jensen, Macleay bacteriologist of the Linnean Society of New South Wales, Sydney, has been appointed chief of the Division of Bacteriology of the State Laboratory of Plant Culture, Danish Ministry of Agriculture.

AT the annual general meeting of the British Standards Institution, held on June 27, Lord McGowan, of Imperial Chemical Industries, Ltd., was elected president in succession to Lord Woolton; and Sir Clifford Paterson, director of the Research Laboratories of the General Electric Co., Ltd., chairman of the General Council in succession to Sir William Larke.

The Society of Dyers and Colourists is organising a symposium on "Recent Advances in the Theory and Practice of Dyeing" to be held at Blackpool during September 25-27. Those likely to attend are asked to communicate with the General Secretary, The Society of Dyers and Colourists, 32-34 Piccadilly, Bradford.

A CONFERENCE on "Emission Spectra of the Night Sky and Auroras" is to be held in the rooms of the Royal Society during July 7-10. Among the speakers from outside Britain will be G. Dejardin, J. Dufay and R. Bernard (Lyons), D. Barbier, J. Cabannes, A. and E. Vassy, J. Bricard and A. Kastner (Paris), C. T. Elvey (Inyokern, California), J. Kaplan (Los Angeles), M. Nicolet (Brussels), E. O. Hulbert (Washington), R. Grandmontagne (Villeurbanne, Rhone), L. Harang (Tromsö), L. Vegard and C. Størmer (Oslo) and H. Alfvén (Stockholm). 